\title{
KENNISDOCUMENT
}

\section{Het belang van dispersie en connectiviteit voor macroinvertebraten en planten}

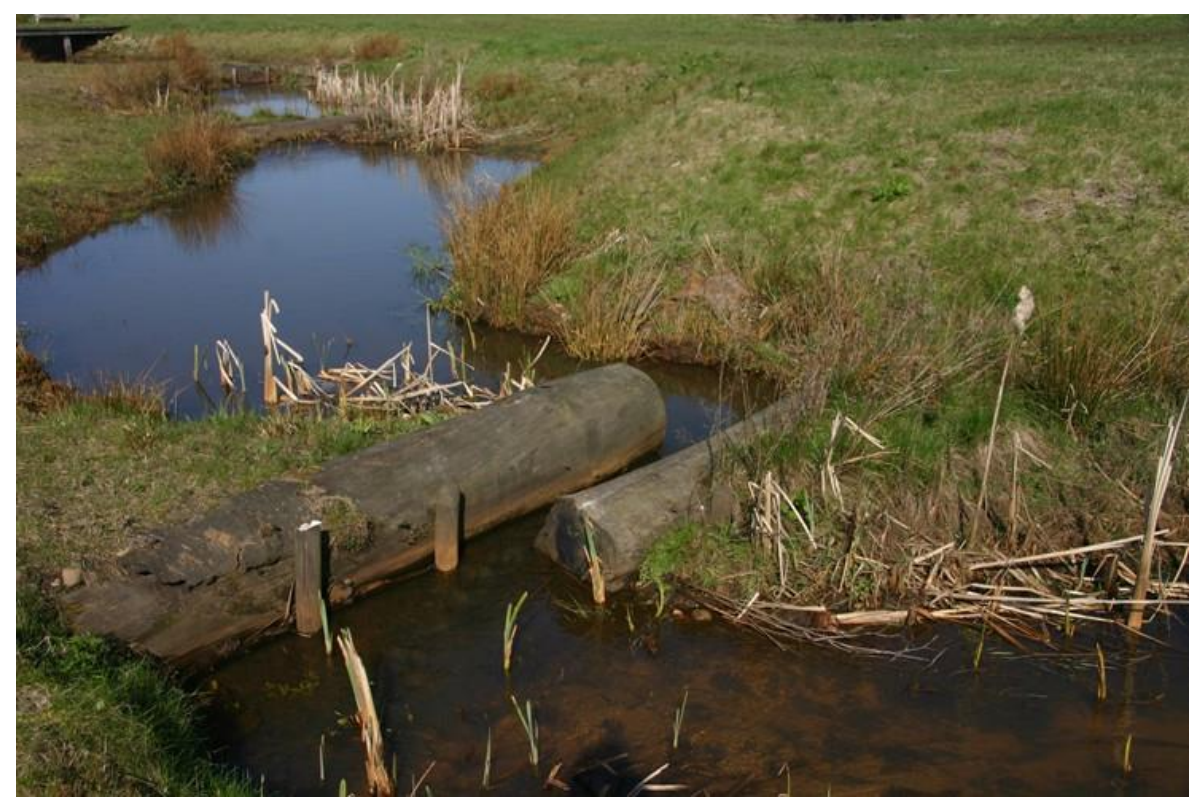

Piet F.M. Verdonschot \& Ralf C.M. Verdonschot 


\section{Referaat}

Veel herstel blijft achter omdat soorten het herstelde water niet kunnen bereiken. Soorten proberen zich steeds van plaats naar plaats te verspreiden, maar dat is niet voor alle soorten even gemakkelijk. De verspreiding verschilt van soort tot soort door verschillen in verspreidingscapaciteit, de wijze van verspreiding, afstand tot de nieuwe plek, milieu-omstandigheden op de nieuwe plek en in het te overbruggen landschap. Planten verspreiden zich alleen passief, laten zich meenemen door wind, water of dieren. De meeste kleine waterdieren verspreiden zich ook vooral passief. Vissen verspreiden vooral actief. Om verspreiding naar herstelde oppervlaktewateren te verbeteren is tijdens herstel aandacht nodig voor de doelsoorten en hun verspreidingsmogelijkheden. Op basis van deze informatie kunnen extra maatregelen nodig zich om bronpopulaties te versterken en de verbinding met het herstelde water te verbeteren.

\section{Auteurs}

Verdonschot P.F.M. \& Verdonschot R.C.M. (correspondentie: piet.verdonschot@wur.nI)

\section{Opdrachtgever}

Kennisimpuls waterkwaliteit (KIWK)

\section{Projectgroep}

Gebruikerscommissie Kennisimpuls waterkwaliteit Systeemkennis ecologie en waterkwaliteit

\section{Leesgroep}

Tom Buijse (Deltares), Peter van Puijenbroek (Planbureau voor de Leefomgeving), Dorien Roubos (Waterschap Vallei \& Veluwe)

\section{Wijze van citeren}

Verdonschot P.F.M. \& Verdonschot R.C.M. (2020). Het belang van dispersie en connectiviteit voor macroinvertebraten en planten. Kennisdocument Kennisimpuls waterkwaliteit (KIWK), Zoetwaterecosystemen, Wageningen Environmental Research, Wageningen UR, Wageningen. 16 pp.

\section{Trefwoorden}

Metapopulatie, Bronpopulatie, Kolonisatie, Passieve verspreiding, Actieve verspreiding, Landschapsfragmentatie, Connectiviteit, Barrière

\section{Beeldmateriaal}

Piet Verdonschot

DOI: https://doi.org/10.18174/544232

Dit project is uitgevoerd in opdracht van de Kennisimpuls waterkwaliteit (KIWK).

(C) 2021 Zoetwaterecosystemen, Wageningen Environmental Research

- Overname, verveelvoudiging of openbaarmaking van deze uitgave is toegestaan mits met duidelijke bronvermelding.

- Overname, verveelvoudiging of openbaarmaking is niet toegestaan voor commerciële doeleinden en/of geldelijk gewin.

- Overname, verveelvoudiging of openbaarmaking is niet toegestaan voor die gedeelten van deze uitgave waarvan duidelijk is dat de auteursrechten liggen bij derden en/of zijn voorbehouden.

Wageningen Environmental Research aanvaardt geen aansprakelijkheid voor eventuele schade voortvloeiend uit het gebruik van de resultaten van dit onderzoek of de toepassing van de adviezen. 


\section{Inhoud}

Inhoud

$1 \quad$ Inleiding

2 Rol en belang van verspreiding 3

2.1 Metapopulatie $\quad 3$

$\begin{array}{lll}2.2 & \text { Afstand vanaf de bronpopulatie } & 3\end{array}$

$\begin{array}{lll}2.3 \text { Kolonisatie } & 4\end{array}$

$\begin{array}{lll}2.4 & \text { Passieve verspreiding } & 4\end{array}$

$\begin{array}{lll}2.5 & \text { Actieve verspreiding } & 6\end{array}$

3 Landschapsfragmentatie en -verbinding (connectiviteit) 9

3.1 Inleiding $\quad 9$

$\begin{array}{llr}3.2 & \text { Barrières in het water } & 9\end{array}$

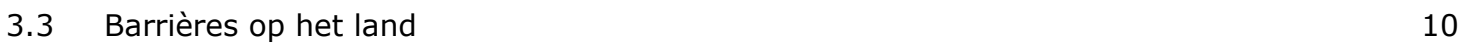

4 Maatregelen $r$

4.1 Verhogen van het kolonisatiepotentieel 11

4.2 Versterken van bronpopulaties. 11

4.3 Verbeteren van de dispersieroute $\quad 11$

4.4 Opheffen barrières binnen en tussen wateren. 12

$\begin{array}{lll}4.5 & \text { Permanente connectiviteit } & 13\end{array}$

5 Conclusies $r$

6 Literatuur $r$ 


\section{Inleiding}

Dit kennisdocument gaat over de verspreiding van macroinvertebraten en waterplanten in regionale wateren. Omdat populaties niet altijd blijven is voor iedere soort verspreiding noodzakelijk. Verspreiding is afhankelijk van de verspreidingscapaciteit van de soort, de omvang van bronpopulatie, de afstand, de kwaliteit van de verbinding en de kolonisatiecapaciteit.

Veel voor Nederlandse oppervlaktewateren karakteristieke soorten zijn reeds uit vele wateren verdwenen. In de overgebleven nagenoeg natuurlijke wateren is sprake van restpopulaties. Deze vaak geïsoleerde populaties handhaven zich onder relatief geschikte (meer natuurlijke) milieu-omstandigheden. Tegelijkertijd zijn ze kwetsbaar. Een enkele calamiteit kan deze populaties doen verdwijnen. Bij te geïsoleerde populaties treedt ook genetische verarming op (Dillon 1988). Deze nagenoeg natuurlijke wateren en hun karakteristieke bewoners zijn van groot belang voor eventuele toekomstige herkolonisatie van herstelde wateren. Verspreiding vanuit deze zogenaamde bronpopulaties is de enige mogelijkheid voor vestiging van soorten, behalve herintroductie door de mens.

Organismen verplaatsen zich in de ruimte binnen en tussen populaties, en naar nieuwe locaties. De verplaatsingen zijn ondergebracht in drie begrippen.

Home range omvat het gebied dat een individu gebruikt voor alle 'routine bewegingen' om te voeden, schuilen, paren en opgroeien (het gebruik van de bestaansbronnen om de levenscyclus te voltooien; Börger et al. 2008).

Migratie is de seizoensgebonden beweging (voedsel en niet-voedsel gebonden) van organismen tussen gebieden. Migratie kan dus onderdeel zijn van de home-range van een organisme.

Dispersie is het mechanisme om nieuwe gebieden te koloniseren. Kolonisatie is het vestigen van een nieuwe populatie door één of meer zich verspreidende individuen. Bohonak \& Jenkins (2003) definiëren dispersie als de beweging van individuen over de grenzen van de populatie. Zij beschouwen kolonisatie als een categorie van dispersie en ook de uitwisseling van individuen tussen populaties binnen een metapopulatie. Kortom er is sprake van dispersie als het organisme zich naar een andere populatie, locatie of habitat begeeft. Dat betekent ook dat migratie gericht en voorspelbaar is terwijl dispersie dat niet is (Danthanarayana 2012).

De verspreidingscapaciteit verschilt tussen organismegroepen en tussen individuele soorten. De combinatie van een beperkte verspreidingscapaciteit van soorten, de aard van de verspreidingsvector, de afstand en een door fragmentatie van het landschap beperkte verspreidingsmogelijkheid wordt vaak gezien als tijd vertragende factor in het herstel van een waterecosysteem na het uitvoeren van een maatregel.

Succesvolle dispersie treedt vooral op onder soorten water- en oeverplanten en ongewervelden met een korte levenscyclus die veel kleine, lichte propagulen produceren (o.a. Brederveld et al. 2011). Dit betreft zogenaamde r-strategen of vroege kolonisten. Dergelijke plantaardige en dierlijke propagulen verspreiden gemakkelijk via de wind van zaden of van cysten (o.a. Soons et al. 2004), door het water (drijfvermogen van zaden of eitjes) (Nilsson et al. 2002, Boedeltje et al. 2004), door watervogels (passeren ongeschonden de darm, blijven aan de veren of poten hangen) (Soonset al. 2008) en zijn persistent (grote zaadbank) (Thompson et al. 1997). Organismen met zwaardere zaden of hoger gewicht (bijvoorbeeld slakken) verspreiden moeilijker en daardoor heeft fragmentatie op deze soorten een groter effect. Dit leidt tot de stelling dat hoe lichter de propagulen hoe gemakkelijker de verspreiding (Finlay \& Fenchel 2004). Daarnaast zullen actief verspreidende soorten beter in staat zijn om ongunstige landschapsfragmenten te overbruggen dan passief verspreide soorten van vergelijkbare grootte, omdat de verspreiding van de laatste meer onderhevig is aan willekeur. 


\section{Rol en belang van verspreiding}

\subsection{Metapopulatie}

Een metapopulatie bestaat uit een aantal ruimtelijk gescheiden of lokale populaties waartussen uitwisseling van individuen plaats vindt. Een lokale populatie wordt bepaald door de lokale milieu-omstandigheden en biotische interacties die soorten als het ware 'uitfilteren' en door de verspreiding van soorten tussen locaties (Leibold \& Miller 2004). De structuur van een metapopulatie is afhankelijk van lokale en regionaal ruimtelijke milieu-omstandigheden factoren. Op de plaatsen met de geschikte habitat- en milieuomstandigheden komt een populatie voor. Tussen deze plaatsen zijn de omstandigheden minder tot niet geschikt (Figuur 1.1). Deze regionaal ruimtelijke milieu-omstandigheden tussen populaties zijn voor waterorganismen bijvoorbeeld land, fysische barrières (b.v. stuwen) en fysische weerstand (b.v. wind, stroming). Om deze omstandigheden te overbruggen (b.v. bij het tegen de stroom in zwemmen) moet een organisme energie gebruiken wat ten koste gaat van andere levensbehoeften.

Wanneer uitwisseling tussen populaties die samen een gemeenschap vormen vrijwel afwezig is, dan is de dynamiek in de samenstelling van de lokale gemeenschappen zeer beperkt: m.a.w. er is een grote invloed van ongunstige regionaal ruimtelijke milieu-omstandigheden. Bij een toenemende mate van uitwisseling wordt de rol van de filterwerking door lokale habitat- en milieu-omstandigheden belangrijker. $\mathrm{Bij}$ nog frequentere uitwisseling zullen door massa-effecten van enkele soorten, ook deze voor het betreffende habitat inferieure (minder aan de betreffende habitat- en milieu-omstandigheden aangepaste soorten) soorten kunnen bestaan binnen een minder bij de betreffende soort horende gemeenschap (Mouquet \& Loreau 2003). Wanneer massa-effecten regionaal overheersen ontstaat een sterke ruimtelijke metagemeenschapsstructuur die tenslotte in feite eindigt in zijnde één gemeenschap.

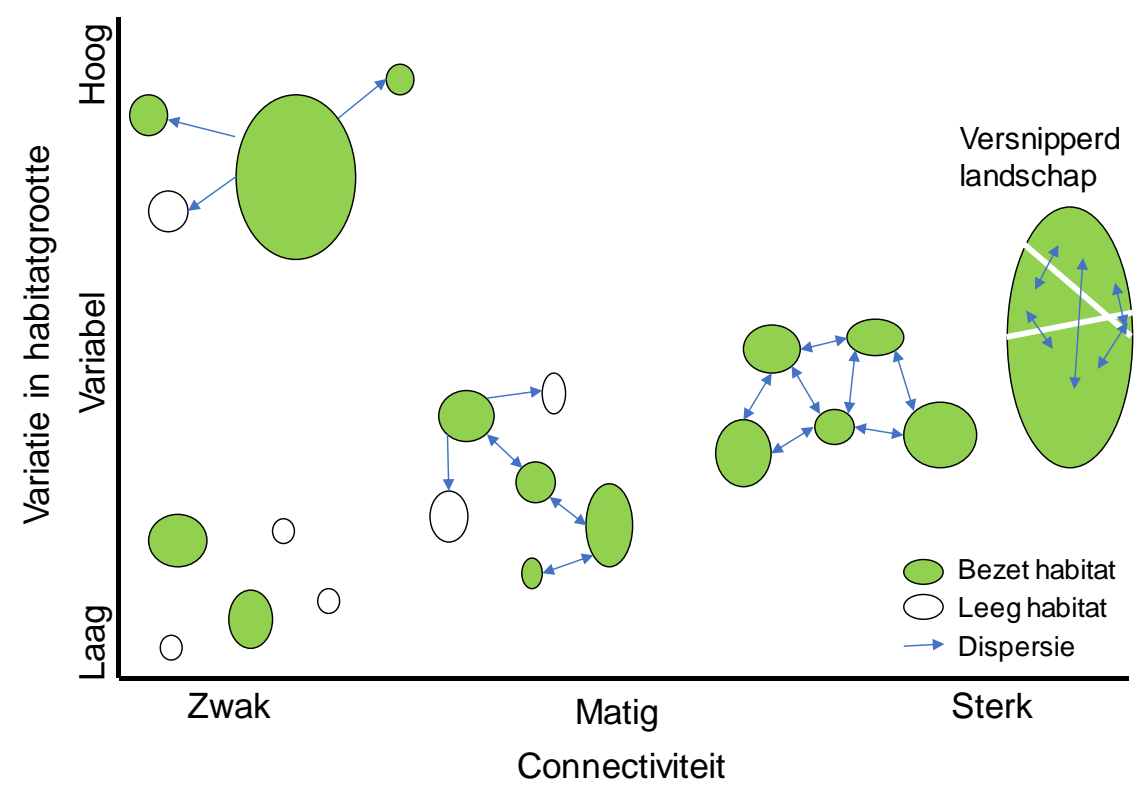

Figuur 1.1: Een metapopulatie omvat een brede range aan situaties in een gebied met kleinere of grotere meer geschikte habitats (verticale as) waartussen minstens enige uitwisseling (afhankelijk van de mate van verbinding; horizontale as) van individuen plaats vindt.

\subsection{Afstand vanaf de bronpopulatie}

Belangrijk voor kolonisatiesucces is naast de aanwezigheid van een abundante lokale of regionale soortenpopulatie (Brederveld et al. 2011) een overbrugbare afstand. De afstand tussen de bronpopulatie en het te koloniseren water wordt zoals hierboven beschreven bepaald door de mate van geschiktheid van de regionaal ruimtelijke milieu-omstandigheden en de absolute afstand zelf. De afstand is overigens voor macroinvertebraten belangrijker dan de aanwezigheid van barrières (Tonkin et al. 2014). 
De meeste verplaatsingen van macroinvertebraten over land of door de lucht spelen zich binnen de zone van circa 1 kilometer of minder ten opzichte van een waterlichaam af, waarbij dieren zowel parallel aan het water als lateraal van het water af kunnen verplaatsen, bijvoorbeeld tussen een lijnvormig water en de aanliggende wateren (bijv. poelen en moerassen). De afstand van verplaatsingen in het water zijn mede afhankelijk van de waterbeweging (passieve of actieve verplaatsing). Beken en rivieren kennen een grote stroomafwaartse component (zogenoemde drift) waarvan vooral veel insectenlarven gebruik van maken en dit strekt over enkele tot tientallen kilometers. Verplaatsingen langs en van een waterlichaam af vinden bij waterinsecten veelal vliegend plaats, terwijl niet-insecten andere dispersiestrategieën kennen, zoals meeliften met andere organismen (mijten op insecten, bloedzuigers en slakken met watervogels etc.). De afstand die in het waternetwerk afgelegd wordt is vooral afhankelijk van de onderlinge verbindingen. In beken is de kans het grootst dat macroinvertebratensoorten die al in het stroomgebied aanwezig zijn, trajecten die door het nemen van maatregelen geschikt geworden zijn als leefgebied op korte termijn koloniseren. Zijdelingse of laterale dispersie is veel meer beperkt ten opzichte van de verplaatsingen binnen een stroomgebied (Westveer 2018) en gaat vaak over tientallen tot honderden meters.

Sundermann et al. (2011) concludeerden dat de afstand waarbinnen nog regelmatige dispersie van beek naar beek plaatsvindt circa $5 \mathrm{~km}$ is. Succesvolle dispersie is daarbuiten veel minder waarschijnlijk en de kans op kolonisatie door macroinvertebraten is dan ook een lange-termijn-proces.

\subsection{Kolonisatie}

Soorten dispergeren niet omdat ergens een habitat hersteld is maar verlaten hun populatie door te hoge dichtheid, om inteelt te voorkomen, door ongunstige biotische of milieu-omstandigheden ter plaatse (bijvoorbeeld concurrentie of milieudegradatie), op zoek naar voedsel, naar een partner of door toeval (bijvoorbeeld verwaaiing). De kans om een nieuwe geschikte locatie te vinden staat niet op voorhand vast (Malmqvist 2002). Dispersie is echter pas succesvol is als het organisme zich ook kan voortplanten in de nieuwe omgeving (Wesselingh et al. 1999). Voor succesvolle kolonisatie is het bereiken van een nieuw habitat niet genoeg maar de soort moet een populatie kunnen opbouwen (groei en overleving). Organismen die veel propagulen produceren (zoals plantfragmenten of eitjes) of die aseksueel voortplanten hebben een grotere kans op succesvolle dispersie.

\subsection{Passieve verspreiding}

\section{Passieve verspreiding}

Organismen kunnen zich actief of passief verspreiden. De meeste soorten uit macroinvertebraten families verspreiden zich hoofdzakelijk passief en zowel het aantal families als de aantallen organismen die passief dispergeren zijn vele male groter dan de actieve verspreiders. Bij passieve dispersie komt vaak een klein formaat ruststadium voor met afgenomen metabolische snelheid en resistentie tegen droogte en extreme temperaturen (Williams 1987). Dergelijke propagulen zijn waarschijnlijk geëvolueerd onder andere omstandigheden, bijvoorbeeld droogval, een afname van voedselbeschikbaarheid of temperatuur in een bepaald seizoen (Bilton et al. 2001). De mate waarin passieve dispersie plaatsvindt, hangt af van de soort en de omstandigheden. Waarschijnlijk is voor de verspreiding van een soort en het uitwisselen van genetische informatie tussen populaties de verspreiding van enkele individuen per generatie voldoende. Hierbij spelen karakteristieken van een soort, zoals het aantal nakomelingen, natuurlijk ook een rol. Er zijn verschillende vormen van passieve dispersie:

- Temporele passieve verspreiding

- $\quad$ Passief transport door dieren (epi- en endozoöchorie) (Figuerola \& Green 2002, Soons et al. 2008).

- Passief transport door de mens.

- Passief transport door stromend water (hydrochorie, o.a. drift) (Nilsson et al. 2002, Gurnell et al. 2008).

- $\quad$ Passief transport door de wind (anemochorie; Soons 2006, Vanschoenwinkel et al. 2008). 
Sommige macroinvertebraten kunnen zich temporeel verspreiden door de accumulatie en vrijkomen van in rust zijnde propagulen die als het ware een reservoir vormen van genetisch materiaal, zoals steekmugeitjes die 4 jaar in rust kunnen blijven voordat ze uitkomen (Bilton et al. 2001), bij steenvliegeitjes (Zwick 1996) en bij zoöplankton die $>200$ jaar in het sediment kunnen overleven (Hairston et al. 1995). Planten kunnen een zaadbank vormen waarvan de zaden jaren later nog kunnen kiemen. Dergelijke dispersie over de tijd is afhankelijk van de rustperiode van levensvatbare propagulen en dat varieert van soort tot soort.

\section{Passief transport door dieren (zoöchorie)}

Watervogels kunnen propagulen van dierlijke en plantaardige aquatische organismen over lange afstanden transporteren (o.a. Figuur 2.1). Er zijn twee mogelijkheden (Darwin 1859, Ridley 1930):

- Interne dispersie (endozoöchorie): aquatische organismen of onderdelen daarvan worden opgegeten en in het spijsverteringskanaal meegedragen.

- Externe dispersie (ectozoöchorie): aquatische organismen of onderdelen daarvan worden aan de buitenkant van het lichaam meegedragen, bijvoorbeeld tussen de veren of poten.

Onderzochte voorbeelden van externe verspreiding zijn de verspreiding van fonteinkruiden, watervlooien, kreeftachtigen, slakken, mossels en visseneieren. Extern transport treedt ook frequent op. Vivian-Smith \& Stiles (1994) bijvoorbeeld observeerden dat aan de veren en poten van 28 van de 36 onderzochte ganzen en eenden zaden gekleefd waren van planten.

Bekende voorbeelden van interne verspreiding zijn die van plantenzaden, zoö- en fytoplanktonsporen en kreeftachtigen. De dispersie en overleving van zaden, eieren en andere propagulen is ook afhankelijk van de vogelsoort (De Vlaming \& Proctor 1968), de door de vogel afgelegde afstand en de verblijftijd in het maagdarmstelsel. Niet alleen vogels transporteren propagulen ook waterinsecten (b.v. waterkevers, waterschorpioenen, waterwantsen, libellen, kokerjuffers, langpootmuggen, vedermuggen) en zoogdieren kunnen als vectoren fungeren. Zo transporteren waterinsecten onder andere algen, protozoën, schimmels, erwtenmosselen, mosselkreeftjes, napjesslakken en watermijten. Ook zaden van planten kunnen via kleinere dieren en ook door vissen worden verspreid.

Passieve dispersie met vogels kan alleen optreden als (Wesselingh et al 1999):

- De soort abundant voorkomt in gebieden waar vogels rusten en voedsel zoeken.

- $\quad$ De soort de mogelijkheid heeft zich aan de vogel vast te klampen/of door de vogel bij de voeding opgenomen wordt.

- $\quad$ De soort een methode heeft om zich te beschermen tegen verdroging.

- $\quad$ De soort opname door de vogel kan overleven.

- $\quad$ De soort zich gemakkelijk kan voortplanten, in het ideale geval vanuit een enkel individu, als deze in een nieuw habitat terechtkomt.

\section{Passief transport door de mens}

Mensen hebben meer en meer gezorgd voor de verspreiding van aquatische soorten (Bilton et al. 2001). Voorbeelden hiervan zijn (o.a. Figuur 2.1):

- $\quad$ Ontsnappen of vrijlaten van soorten uit viskwekerijen, vijvers, aquaria en tuincentra.

- $\quad$ Meeliften in ballastwater van schepen, zelfs tussen continenten.

- $\quad$ Gefaciliteerd worden door de aanleg van kanalen tussen grote rivieren (b.v. het RijnDonaukanaal).

- $\quad$ Het uitzetten vaak van soorten voor de 'bestrijding' van andere soorten (b.v. graskarpers).

\section{Passief transport door stromend water (drift)}

Drift is een vorm van passieve dispersie in stromende wateren (Bilton et al. 2001). Bij drift worden organismen stroomafwaarts getransporteerd. Drift is relevant als hierdoor discrete populaties met elkaar verbonden worden (Bilton et al. 2001). Drift kan ook zorgen voor kolonisatie van een benedenstrooms gelegen hersteld beektraject. Drift kan in vier categorieën onderscheiden worden:

- $\quad$ Catastrofische drift veroorzaakt door extreme afvoerpieken, lozing van gifstoffen, warm water of droogval (Minckley 1964).

- $\quad$ Gedragsdrift tijdens dagelijkse activiteit (vooral 's nachts) en door het actief opzoeken van de kolom (Waters 1965).

- $\quad$ Verspreidingsdrift over korte en lange afstanden (Allan 1984, Brittain \& Eikeland 1988).

- Constante of achtergronddrift bij b.v. het toevallig losraken. 
Drift is één van de belangrijkste mechanismen waardoor in beken een grote stroomafwaarts gerichte verplaatsing van de fauna kan optreden. Drift leidt hierdoor tot een verlies van de populatie bovenstrooms. Compensatie treedt op door een kolonisatiecyclus (volwassen dieren vliegen terug naar het bovenstroomse beekgedeelte: Müller 1954), door stroomopwaartse verspreiding van larven en nimfen over en door de beekbodem en in mindere mate door de waterkolom en oever, en door hoge reproductie. Drift kan ook een gevolg zijn van dichtheidsafhankelijke regulatie die alleen optreedt om intraspecifieke competitie te reduceren (Elliott 1967a).

Over het algemeen geldt voor planten dat zowel seksuele als aseksuele propagulen een significante dispersiecapaciteit hebben binnen en tussen hydrologisch met elkaar verbonden wateren. Aseksuele propagulen verspreiden zich minder naar geïsoleerde waterlichamen en tussen niet verbonden stroomgebieden (uitgezonderd zijn delen van zeer kleine planten zoals Riccia, Azolla en Lemna). In een onderzoek waarin diasporen van planten benedenstrooms van een genormaliseerde beek zijn opgevangen, is gebleken dat van de drijvende planten $100 \%$ van de gevangen diasporen vegetatief was, van de submerse waterplanten $98.9 \%$ en van de emergente planten $23.7 \%$ (Boedeltje et al. 2003). Deze laatste groep is voor dispersie meer afhankelijk van zaden. Dit geldt ook voor oever- en moerassoorten waarvan maar $2.9 \%$ van de diasporen vegetatief is. Veel zaden hebben drijfvermogen en worden verspreid via het water en de wind.

\section{Passief transport door de wind}

Winddispersie kan belangrijk zijn voor het verspreiden van kleine, droogteresistente stadia bijvoorbeeld van zoöplankton (Bilton et al. 2001), zaden en sporen (o.a. Figuur 2.1). Ook vliegende volwassen insecten worden passief verspreid door de wind. Winddispersie over langere afstand treedt vooral op bij slecht vliegende insecten, zoals steenvliegen, eendagsvliegen, kokerjuffers en sommige Diptera (Kelly et al. 2001). Freeman (1945) trof in lagere en hogere luchtlagen zogenaamde hoogvliegers aan; individuen van eendagsvliegen (Ephemeroptera), kevers (Coleoptera), langpootmuggen (Tipulidae), vliegen (Ephydridae), vedermuggen (Chironomidae) en knutten (Ceratopogonidae).

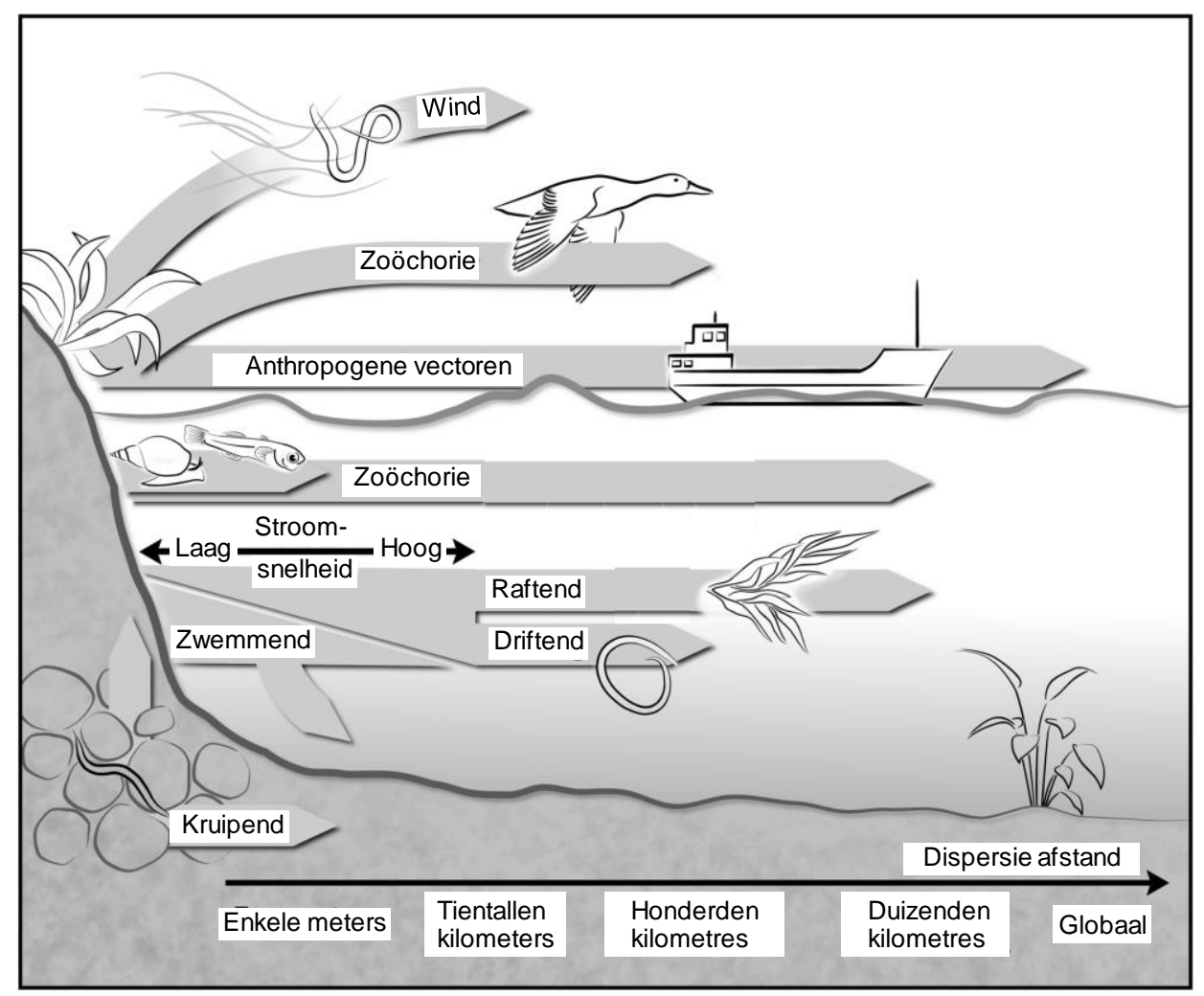

Figuur 2.1: Illustratie van de afstanden bij verschillende vormen van transport voor passieve e actieve verspreiding van nematoden (overgenomen uit Ptatscheck \& Traunspurger 2020).

\subsection{Actieve verspreiding}


Actieve verspreiding kan worden onderverdeeld in:

- Actieve verspreiding door de lucht (Elliott 1971, Turner \& Williams 2000).

- Actieve verspreiding over land.

- Actieve verspreiding door het water.

Actieve verspreiding door de lucht

Adulte insecten kunnen zich verspreiden door te vliegen. Goede vliegers worden aangetroffen bij veel libellen (Odonata; Corbet 1963), sommige kevers (Coleoptera; Balfour-Browne 1958, Dytiscidae, Hydrophilidae; Gray \& Fisher 1981), sommige wantsen (Hemiptera; Macan 1939, Corixidae; Gray \& Fisher 1981) en sommige kokerjuffers (Trichoptera; Svensson 1974, Bouvet 1977), kriebelmuggen (Simuliidae; Davies 1961), sommige steenvliegen (Schwartz 1970, Madsen et al. 1973; met name Nemoura cinerea; Engblom et al. 1981a), sommige eendagsvliegen (Madsen et al. 1973) met name Leptophlebia marginata, L. vespertina, Baetis rhodani (Engblom et al. 1981a), Baetis alpinus (Lavandier 1982)) en steekmuggen (Culicidae; Provost 1952). Veel van deze goede vliegers zijn wijd verspreid over geschikte habitats.

De afstanden waarover deze soorten vliegen verschillen. Voor steekmuggen (Culicidae) suggereren de data dat adulte dispersie in de meeste soorten beperkt is tot $<5 \mathrm{~km}$ (Service 1997) en in sommige gevallen zelfs $<1 \mathrm{~km}$. Maar met behulp van wind kunnen steekmuggen zich soms veel verder verspreiden zoals Culex pipiens, waarvan adulten een afstand van meer dan $20 \mathrm{~km}$ wisten te overbruggen (Verdonschot et al. 1988). Generalisaties zijn niet te maken, behalve dat kleinere kokerjuffersoorten kortere afstanden afleggen dan grotere soorten. De afmetingen van de vleugel spelen hierbij zeker een rol maar ook de wijze waarop de vliegspieren van energie worden voorzien. Voor libellen geldt ook dat sommige soorten op grote schaal migreren en andere zich slechts verspreiden over zeer korte afstanden (o.a. McPeek 1989).

Andere soorten zijn slechte vliegers, zoals de meeste eendagsvliegen (Ephemeroptera; Edmunds et al. 1976), kokerjuffers (Trichoptera; Ross 1956) en vedermuggen (Chironomidae; Davies 1976), veel steenvliegen (Plecoptera; Hynes 1976), sommige wantsen (Naucoridae; Gray \& Fisher 1981) en sommige kevers (Coleoptera; Jackson 1956). In tegenstelling hiermee concludeert Roos (1957) dat 70-80\% van alle volwassen vrouwtjes van reofiele kokerjuffers, eendagsvliegen, steenvliegen en kriebelmuggen (Simuliidae) stroomopwaarts vliegen. Sommige soorten hebben vleugelloze volwassen vormen (vooral bij wantsen, steenvliegen en kokerjuffers). De afgelegde vliegafstand hangt ook af van het landschap en het weer.

In het algemeen is de dispersiesnelheid binnen een stroomgebied hoger dan tussen gescheiden stroomgebieden, zelfs bij actief vliegende soorten. De stroomopwaartse gerichte vliegbeweging is 3-5 maal zo groot als de stroomafwaartse vlucht bij insecten. De stroomopwaartse afstanden variëren ongeveer 1 $\mathrm{km}$ tot circa $20 \mathrm{~km}$. De lateraal gerichte vliegbeweging is beperkt, vooral bij zwakke vliegers zoals Trichoptera en Plecoptera waarvan 50\% niet verder gevonden werd dan 11-16 m van de beek en $90 \%$ niet verder dan $51 \mathrm{~m}$. Ephemeroptera vliegen vaak nog minder. Echte verspreidingsvluchten zijn wel bekend van kevers (Coleoptera) en vliegen (Diptera) (Fernando \& Galbraith 1970).

De morfologie van insecten lijkt een indicatie te kunnen geven van de dispersiecapaciteit (Hoffsten 2004). De aerodynamica suggereert dat vliegcapaciteit afhangt van totaal lichaamsgewicht, relatieve thorax grootte, vleugel 'loading' (sterkte van de vleugel gerelateerd aan het oppervlak en het gewicht van het dier) en lengte/breedte verhouding van de vleugels (Vogel 1981). De spiermassa en de energievoorziening daarvan in de vleugels (thorax-massa) bepaalt voor een groot deel het vliegvermogen.

\section{Actieve verspreiding over land}

Verspreiding over land, zoals bij bekend van rivierkreeften, is een minder voorkomende manier van verspreiden bij ongewervelde dieren. Verspreiding over land is wel van belang voor gewervelden zoals waterspitsmuis, amfibieën, otters en dergelijke. Sommige adulte insecten die niet goed kunnen vliegen, lopen over land stroomopwaarts om daar hun eieren af te zetten. Verplaatsing via het land vindt plaats langs de oever (zoals waargenomen bij Gammarus spp.) of via natte habitats. Sommige mollusken en nietvliegende kevers kunnen zich via tussenliggende natte habitats naar andere wateren begeven.

\section{Actieve verspreiding door het water}

Veel soorten verspreiden zich door te zwemmen of te kruipen door het water, veelal via luwe zones of langs de waterlijn in stromende wateren. De afgelegde afstanden verschillen per soort. Stroomopwaartse verspreiding heeft in stromende wateren vaak te maken met voedselbeschikbaarheid, het bereiken van een ander stadium (bijvoorbeeld om te verpoppen of om zich voort te planten) of om drift te compenseren. In geïsoleerde wateren heeft dit geen effect op de dispersie maar in stromende wateren kan 
stroomopwaartse of stroomafwaartse beweging ertoe leiden dat andere beektakken gekoloniseerd worden. Stroomopwaartse verspreiding via het water vindt plaats omdat dieren (Söderström 1987):

- Op zoek zijn naar voedsel of ruimte ten behoeve van vermindering van inter-/intraspecifieke competitie.

- Op zoek zijn naar geschikte habitats om uit te vliegen, zich te verpoppen of zich voort te planten.

- Ongunstige abiotische omstandigheden willen vermijden.

- $\quad$ Drift willen compenseren.
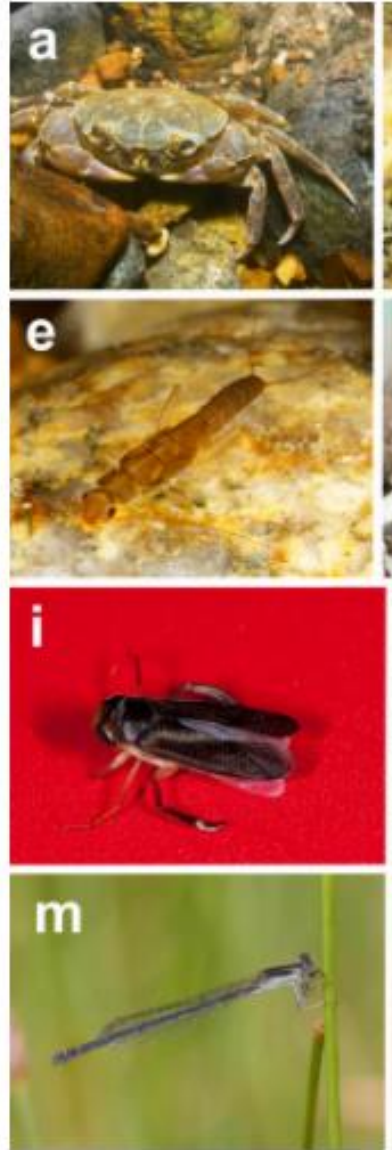
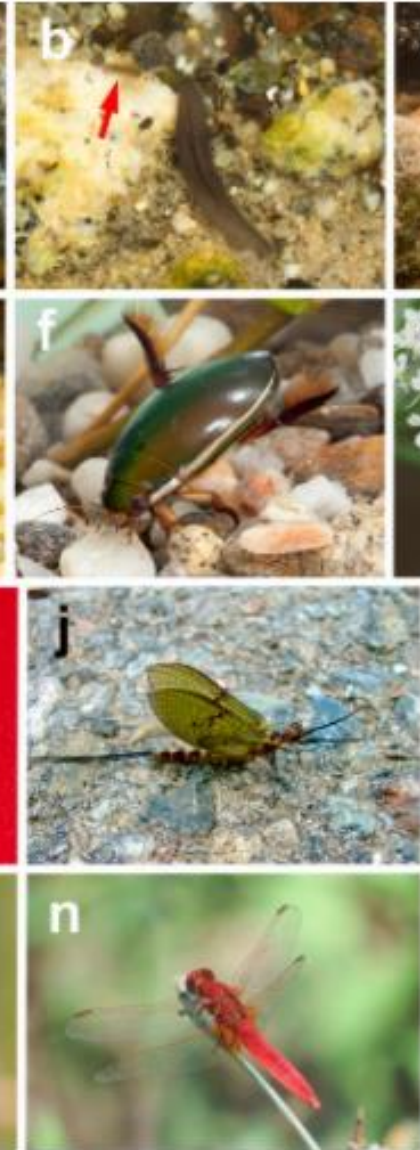
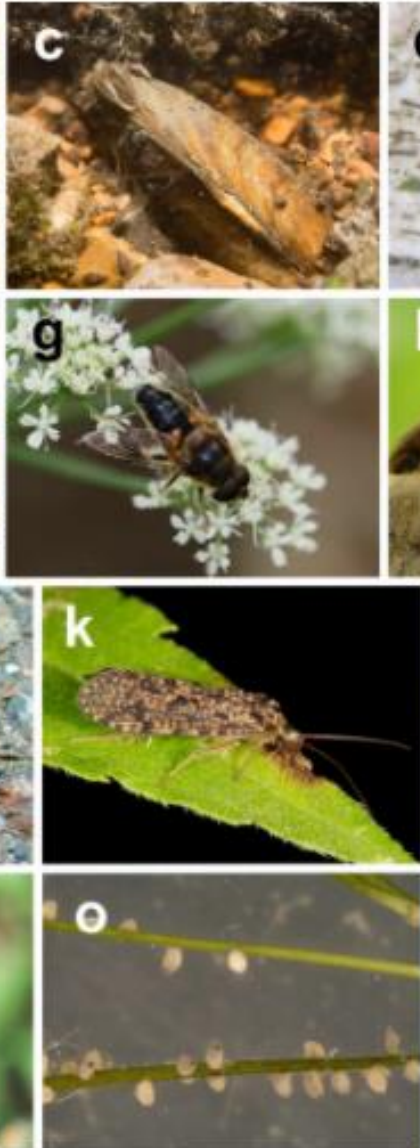
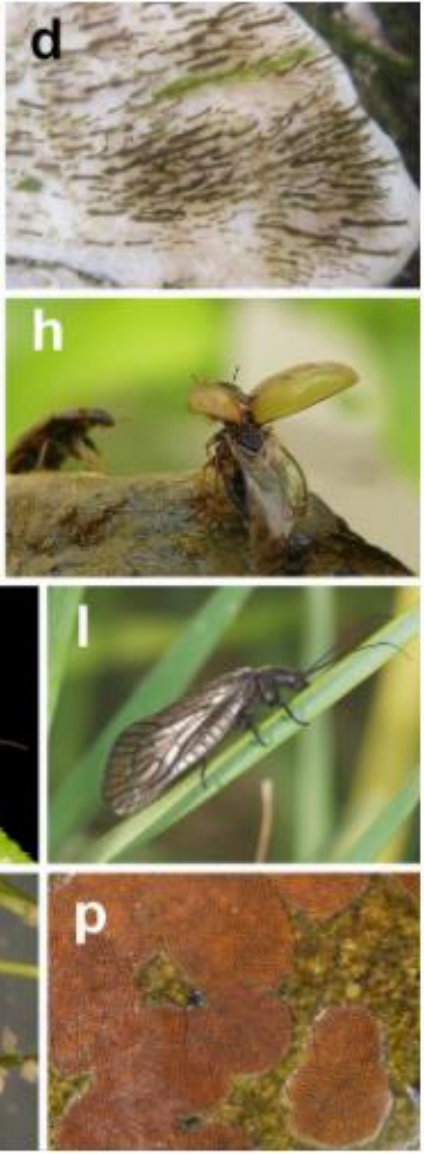

Figuur 2.2: De dispersie gerelateerde diversiteit aan kenmerken van aquatische macroinvertebraten. Taxa die zich verspreiden in water omvatten de kreeftachtigen van de genera Potamon (a) en Asellus (pijl in b), Tricladida (b), tweekleppigen van het genus Unio (c), insectenlarven zoals het tweevleugeligen genus Simulium (d) en het steenvliegen genus Leuctra (e), en volwassen kevers inclusief het roofkever genus Cybister ( $f$ ). Dergelijke aquatische verspreiders kunnen passief bewegen in drift $(c, d)$ en / of actief kruipen of zwemmen $(a, b, e, f)$. De meeste volwassen insecten hebben vleugels en kunnen over land vliegen ( $f-$ n). Vleugels zijn morfologisch divers en omvatten verschillende typen: één vleugelpaar, zoals in Diptera, zoals het zweefvliegen genus Eristalis $(\mathrm{g})$; één paar vleugels met dekschilden zoals bij het kever genus Enochrus (h) of met een dekschild bij het wantsen genus Hesperocorixa (i); twee vleugelparen waarvan één paar kleine achtervleugels voor eendagsvliegen zoals bij het genus Ephemera (j); en twee paar vleugels van vergelijkbare grootte voor het kokerjuffer genus Polycentropus ( $k$ ), het genus van de slijkvliegen Sialis $(I)$ en de libellen genera Ischnura $(m)$ en Crocothemis $(n)$. Vleugels variëren in grootte van enkele $\mathrm{mm}$ in sommige tweevleugeligen $(\mathrm{g})$ tot meer dan $3 \mathrm{~cm}(\mathrm{I}-n)$, waarbij de libellen een voorbeeld zijn van de grote morfologische vormen. Taxa variëren in het aantal geproduceerde eieren per vrouwtje, variërend van tientallen per reproductiecyclus voor de meeste kevers en wantsen, zoals het geslacht Sigara (o) tot enkele honderden in de eiermassa's van de meeste eendagsvliegen en kokerjuffers, zoals die van het genus Hydropsyche (p). Overgenomen uit Sarremejane et al. 2020 met daarin dank aan: Adolfo Cordero-Rivera (a-g, $i, k-n)$, Jesús Arribas (h), Pere Bonada (j), José Antonio Carbonell (o) en Maria Alp (p). 


\section{Landschapsfragmentatie en -verbinding (connectiviteit)}

\subsection{Inleiding}

Bij verspreiding van soorten speelt de habitatkwaliteit op de route een belangrijke rol. Bij verspreiding hoeven de omstandigheden op de route niet optimaal te zijn, maar moeten wel aan de minimumeisen van betreffende soort voldoen. De aanwezigheid van verspreidingsbarrières speelt vooral een rol in stromende wateren. Stilstaande wateren zijn meestal geïsoleerd en de belangrijkste barrière tussen stilstaande wateren is het land. Enerzijds zijn verspreidingsbarrières een natuurlijk gegeven, zoals omgevallen bomen en wortelformaties die leiden tot natuurlijke watervallen vooral in bovenlopen van beken. Maar anderzijds zijn er tegenwoordig veel kunstmatige structuren in stromende wateren.

\subsection{Barrières in het water}

Barrières in het water zijn onder andere (Pechlaner 1986):

- $\quad$ Stuwen, bodemvallen, duikers en overkluizingen.

- $\quad$ Ongeschikte trajecten.

Stuwen, bodemvallen, duikers en overkluizingen

Stuwen vormen een duidelijke barrière voor aquatische organismen. Dit geldt niet alleen voor vissen maar ook voor macroinvertebraten en andere soorten die zich stroomopwaarts bewegen. Van macroinvertebraten is weinig bekend over het passeren van stuwen en vispassages.

Over het vermogen van vissen om barrières te passeren is meer bekend, zowel ten aanzien van kenmerken van de vis als ten aanzien van kenmerken van de barrière. Voor een overzicht wordt verwezen naar (Arnoud 1964, Wilke 1970, Bless 1981, Sloane 1984, Verdonschot 1996, Nijboer \& Verdonschot 2006).

De barrièrewerking van een duiker hangt enerzijds samen met de fysische/hydraulische toestand van in- en uitstroomopening en anderzijds van de fysisch/hydraulische omstandigheden in de duiker zelf. Zijn er hoogteverschillen aanwezig tussen beek en instroom (stroomversnelling) of tussen duiker en uitstroom (stroomversnelling en/of waterval), dan levert dit een voor dieren moeilijk passeerbare structuur op, vergelijkbaar met een stuw. Een luwtezone bij de uitstroomopening is een randvoorwaarde voor een passeerbare duiker. Problemen voor fauna bij het passeren van duikers zijn:

- $\quad$ Bij de instroomopening:

- $\quad$ Hoogteverschil/sterk verval leidend tot een stroomversnelling.

- $\quad$ Ophoping van (organisch) materiaal.

- In de duiker zelf:

- $\quad$ Te hoge stroomsnelheid of turbulentie door hoge afvoer of groot verval of te lage stroomsnelheid bij lage afvoeren.

- $\quad$ Ophoping van (organisch) materiaal geeft stroomversnellingen in de duiker of vormt een fysieke barrière.

- $\quad$ Lengte van de duiker in relatie tot de zwemprestatie of de verplaatsingssnelheid van het organisme.

- Gladde structuur.

- $\quad$ Bij de uitstroomopening:

- $\quad$ Hoogteverschil (stroomversnelling of waterval).

- $\quad$ Afwezig zijn van een luwtezone/poel.

Ongeschikte trajecten

Trajecten kunnen door verschillende oorzaken minder of ongeschikt zijn. In stromende wateren kan dit een gevolg zijn van kanalisatie, stagnatie, beschoeiing, stuwing, verslibbing, organische, chemische en thermische belasting en droogval van tussenliggende trajecten. In stilstaande wateren zijn dat vooral compartimentering, verslibbing, organische, chemische en thermische belasting.

De verspreiding van macroinvertebraten tussen stilstaande wateren zoals meren en plassen verloopt meestal passief door wind of actief dor het vliegen over land (Bilton et al. 2001). Dit betekent dat 
nabijgelegen poelen, plassen en meren een onderling meer vergelijkbare soortensamenstelling herbergen dan dergelijke stilstaande wateren veraf (de Bie et al. 2012) ongeacht onderlinge aquatische verbindingen (Heino 2013). Desalniettemin zal ook in stilstaande wateren het milieu als filter op de vestiging werken (Leibold et al. 2004). De waarneming dat dicht bij elkaar gelegen wateren meer gelijkend zijn (ruimtelijke autocorrelatie) kan een gevolg zijn van beperkte dispersiemogelijkheden, bijvoorbeeld door beperkte dispersiecapaciteit van de soort, barrières of een beperkte tijd om een locatie te bereiken (Hubbell 2001, Heino et al. 2015) of van massa-effecten (Mouquet \& Loreau 2003, Heino 2013). Door massa-effecten kunnen nabijgelegen locaties sterk homogeniseren in samenstelling (Vilmi et al. 2016). Toch hebben tussen stilstaande wateren de milieu-omstandigheden in ieder water het grootste effect op de samenstelling (Heino 2013). Milieufactoren zoals hardheid (calciumbeschikbaarheid voor slakken (Aho 1966)), totaal fosfor (algensamenstelling als voedsel component (Heino \& Mutka2006)), macrofyten (structuurheterogeniteit (Tolonen et al. 2001, Johnson \& Goedkoop 2002, Heino 2008)) bepalen of soorten uiteindelijk succesvol zijn of niet. Stilstaand water soorten zijn evolutionair aangepast aan het geologisch korter bestaan en instabieler karakter van stilstaande t.o.v. stromende wateren (Ribera \& Vogler 2000, Hof et al. 2006, Abellan et al. 2009, Damm et al. 2010). Dit betekent dat stilstaand water soorten een grotere dispersiecapaciteit zouden moeten bezitten die mogelijk samenhangt met een groter temperatuur tolerantie. Waarschijnlijk is temperatuur in stilstaande wateren de sleutelfactor voor dispersiesucces. Verstoring van de milieu-omstandigheden in stilstaande wateren vormt dan ook de belangrijkste barrière.

\subsection{Barrières op het land}

Barrières op het land zijn onder andere:

- Ongeschikte terrestrische habitats.

- Het ontbreken van tussenliggende potentiele rustplaatsen.

Voor volwassen insecten kan de terrestrische habitat meer of minder geschikt zijn. De resultaten van onderzoek zijn wisselend. Petersen et al. (2004) vond geen overall effect van verschillen in landgebruik (7 beken vergeleken in heidelandschap, aangeplant naaldbos en gekapt bos) op de verspreiding van beekinsecten. Delettre \& Morvan (2000) daarentegen vonden wel verschil in een heggenlandschap. Het bleek dat de afstand tot de beek bepalend was voor de diversiteit en abundanties van Chironomidae (nam af). Delettre \& Morvan vonden ook hoe meer divers en breder de heg, des te meer individuen hierin rustten. Hoe hoger de dichtheid van de heggen in het landschap, hoe hoger de dispersie.

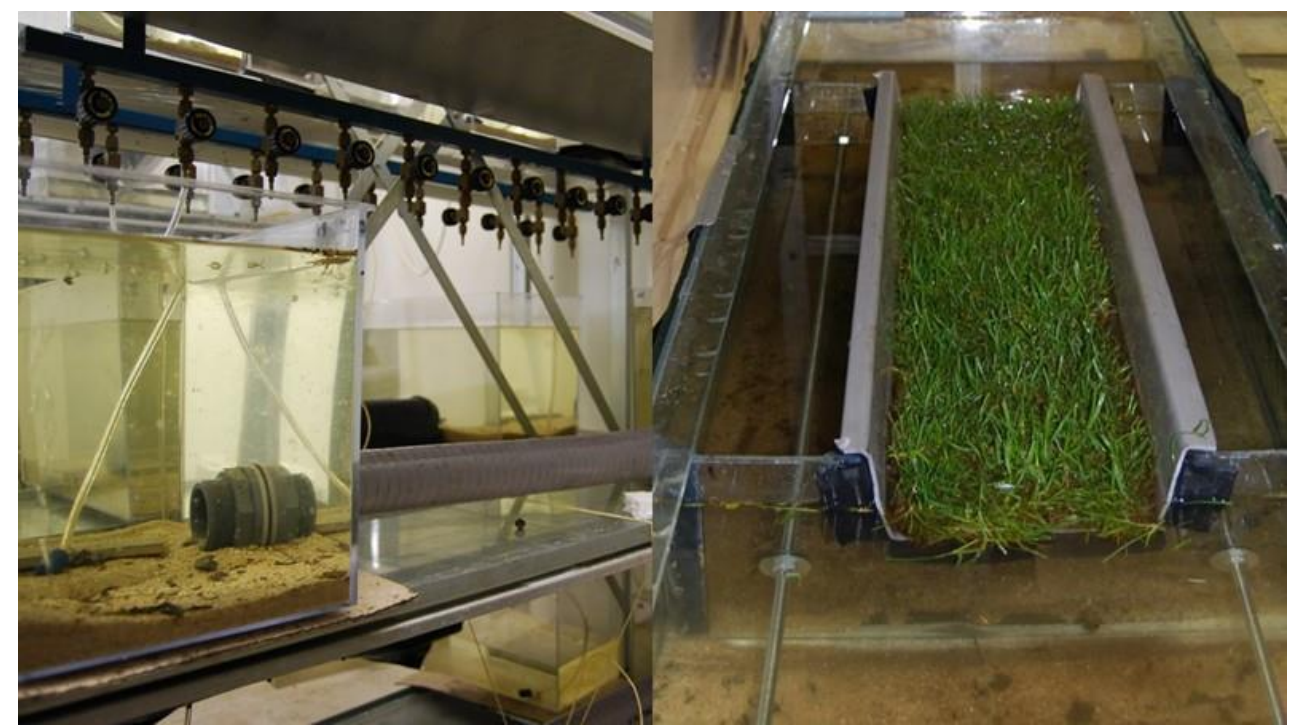

Figuur 3.1: Experimentele opstellingen uit het onderzoek naar dispersiebarrières voor macroinvertebraten (Didderen et al. 2008). 


\section{Maatregelen}

\subsection{Verhogen van het kolonisatiepotentieel}

Maatregelen gerelateerd aan dispersie en connectiviteit hebben tot doel het verhogen van het kolonisatiepotentieel van doelsoorten en kan geschieden door:

- Het versterken van bronpopulaties van doelsoorten.

- Het opheffen van dispersiebarrières. Of versterken van de connectiviteit.

Beide maatregelen kunnen de veerkracht van wateren vergroten (Stubbington et al. 2017).

\subsection{Versterken van bronpopulaties.}

In ieder stilstaand en stromend oppervlaktewater treden natuurlijke en antropogene verstoringen op die soorten kunnen doen verdwijnen. Het versterken van bronpopulaties, populaties die als bron dienen om andere plekken te (her)koloniseren begint met het lokaliseren hiervan. Kennis over het voorkomen van kenmerkende of gevoelige soorten in het gebied is hierbij essentieel, net zoals kennis over de eisen die deze planten- en diersoorten aan ecologische sleutelfactoren, zoals zuurstofregime, stroming, nutriënten concentraties, gedurende het doorlopen van hun levenscyclus stellen. Hierop kan vervolgens worden ingezet door maatregelen te nemen die deze eisen in betreffend oppervlaktewater optimaliseren. Groei van de lokale populaties zorgt ervoor dat er meer potentiele kolonisten beschikbaar komen (soms zelfs als respons op hoge populatiedichtheden), waardoor de kans op (her)kolonisatie van andere wateren toeneemt.

In de aanpak om bronpopulaties te versterken staat een ecologische systeemanalyse voorop. Hoe dichterbij de bronpopulatie zich bevindt, hoe groter de kans op herkolonisatie. Een ecologische systeemanalyse brengt de biologische 'hotspots' in beeld en de milieu-omstandigheden in de habitat van de bronpopulatie en van de kwaliteit van de habitats op de potentiele verspreidingsroute.

\subsection{Verbeteren van de dispersieroute}

Om deze kans toe te laten nemen is ook de kwaliteit van de dispersieroute van belang (Buijse et al. 2019). Dispersie via het water kan alleen als de kwaliteit in het tussenliggende wateren voldoende geschikt is. Bij dispersie via het water spelen de volgende omstandigheden een rol waaraan maatregelen kunnen worden verbonden;

- Waterbeweging

- Kwaliteit van tussenliggende aquatische habitats

Verspreiding via de lucht stelt vaak ook eisen aan de vegetatie, zoals de aanwezigheid van een houtwal in een bufferzone of houtopstanden die kunnen dienen als 'stapstenen'. Hier is de kwaliteit van tussenliggende terrestrische habitats van groot belang.

Waterbeweging in stilstaande wateren

Waterbeweging of eenzijdige afstroming in beken en riviertjes is evident en draagt belangrijk bij aan stroomafwaarts verspreiding. Maatregelen richten zich vooral op de juiste timing van afstroming, het voorkomen van extreme afvoeren en droogval (Verdonschot \& Verdonschot 2020) en het verwijderen van barrières zoals stuwen en sluizen (zie paragraaf barrières behouden of slechten).

Omdat passieve dispersie voor veel aquatische organismen het belangrijkste verspreidingsmechanisme is, is juist in stilstaande wateren waterbeweging in richting en kwantiteit een belangrijke sturende factor. De waterbeweging ontstaat door het peilbeheer. Peilwisselingen kunnen van invloed zijn op de dispersie mogelijkheden. Peilbeheer en de daaraan gekoppelde waterbeweging, is echter nog niet eerder in verband gebracht met het dispersievermogen van aquatische macroinvertebraten in stilstaande wateren. Onderzoek naar het belang en stuurvermogen van deze factor zou de effectiviteit van herstelmaatregelen verder kunnen vergroten.

$\underline{\text { Kwaliteit van tussenliggende aquatische habitats }}$ 
In de aanpak om dispersieroutes via het water te versterken zijn twee aspecten van belang:

- Kennis van de kwaliteitseisen tijdens dispersie van de doelsoorten.

- Kennis van de toestand van de wateren op de dispersieroute.

Kennis van de kwaliteitseisen van doelsoorten tijdens dispersie vraagt kennis over de wijze en duur van verspreiding en het levensstadium. Bij de wijze en duur van verspreiding zijn vooral bewegingsgedrag en -snelheid van belang. Deze combinatie maakt of wel of niet rusthabitats, schuilplekken, voedsel en dergelijke een rol zullen spelen.

Voor het opbouwen van kennis van de toestand van de wateren op de dispersieroute is een ecologische systeemanalyse noodzakelijk. Een ecologische systeemanalyse brengt de milieu-omstandigheden van de habitats op de potentiele verspreidingsroute in beeld. Deze milieu-omstandigheden kunnen worden getoetst aan de eisen die de doelsoorten stellen. Een knelpunten analyse van de hydrologische, morfologische, chemische en biologische omstandigheden volgens de 5S-model systematiek brengt de multiple stressoren in kaart en geeft aanknopingspunten voor maatregelen. Verschillende kennisdocumenten t.a.v. de hydrologische, morfologische, chemische en biologische factoren bieden een scala aan voorbeelden van maatregelen.

\section{Kwaliteit van tussenliggende terrestrische habitats}

De terrestrische imago's van veel waterinsecten zijn relatief slechte vliegers en hebben een beperkt dispersievermogen (Sundermann et al., 2011). De ligging van het te koloniseren water ten opzichte van wateren met potentiële bronpopulaties en het seizoen zijn belangrijke factoren die de kolonisatiesnelheid bepalen (Westveer et al., 2018): hoe dichterbij, hoe gunstiger. Het omliggende landschap en dan met name de aanwezige begroeiing speelt een belangrijke rol bij het faciliteren van dispersie; voor beken geldt bijvoorbeeld dat natte bossen erg geschikt zijn voor beekinsecten om zich dwars op de beek te verplaatsen en zo andere wateren te bereiken (Collier \& Smith, 1998). Dit pleit voor het aanleggen van 'steppingstones' of corridors met geschikt habitat tussen wateren, bijvoorbeeld bosstroken tussen bovenlopen in een bekenstelsel. De kennis over dispersie van macroinvertebraten is echter beperkt, waardoor meer gedetailleerde handvatten op dit moment niet te geven zijn.

\section{Barrières behouden of slechten}

Uit onderzoek in het Natura 2000 gebied de Wieden is gebleken dat isolatie of verbinding leidt tot een verschil in faunasamenstelling van petgaten. Petgaten met een open verbinding bleken na 5 jaar een groot deel van de fauna van een naast gelegen waterlichaam te hebben, terwijl geïsoleerde petgaten een sterk afwijkende faunasamenstelling had ontwikkeld, als waren het eilanden (Didderen 2007). Geïsoleerde petgaten boden tevens habitat voor restpopulaties van bijzondere soorten, zoals de mijt Arrenurus berolinensis (Smit et al 2006). M.a.w. waterverbindingen kunnen gebruikt worden als middel om de aanwezigheid van aquatische organismen te homogeniseren. Het in een groter gebied sommige wateren wel en andere wateren niet te verbinden kan zodoende leiden tot een meer gevarieerde soortensamenstelling. Ook kan een waterbinding, zoals een duiker tijdelijk als regulatiemechanisme worden gebruikt. Zo kan een duiker tijdelijk afgesloten worden bij schoning, bagger- of graafwerkzaamheden, zodat de aquatische organismen uit een naastgelegen water geen negatieve gevolgen ondervinden van de werkzaamheden. Een andere toepassing van isoleren is het tegengaan van exoten. Zo blijkt dat rivierkreeften van de familie Cambaridae slecht in staat zijn door een duiker te bewegen. Een exoot kan als het ware tegen worden gehouden door het isoleren of geïsoleerd houden van wateren (Krieg \& Zenker 2020). Helaas zijn rivierkreeften in staat zich over land te bewegen, waardoor de barrière alleen geldt voor de verplaatsing door het water. Het behouden of slechten van een barrière is afhankelijk van het doel maar in het algemeen zal isoleren naast verbinden de $\beta$-diversiteit sterk verhogen.

\subsection{Opheffen barrières binnen en tussen wateren.}

\section{$\underline{\text { Duikers }}$}

Voor taxa die zich alleen via water kunnen verspreiden, kan een duiker een dispersieprobleem opleveren. De waterverplaatsing van het ene waterlichaam naar het andere blijkt soms zo groot dat er in verbindende duikers hoge stroomsnelheden worden gemeten (tot $0.5 \mathrm{~m} / \mathrm{s}$ ) en passieve dispersie een aanzienlijk grotere rol kan spelen dan actieve dispersie.

Verbeteringen in de stroomopwaartse dispersiemogelijkheden voor aquatische organismen bestaan uit technische aanpassingen aan duikers (Gebhards \& Fisher 1972, Avery 1973, Saltzman \& Koski 1971, Kay \& Lewis 1970, Lauman 1976, Kratt 1981, Bulow et al. 1988, Riemersma 1994). Om de 
verspreiding van aquatische macroinvertebraten door duikers te bevorderen is het aan te raden de duikers zo kort en breed mogelijk te maken met een grote instroomopening om ophoping van (organisch) materiaal te voorkomen en ervoor te zorgen dat er een verbinding is met de bodem, bijvoorbeeld door het aanleggen van een schuin talud (Didderen et al. 2008). Andere aspecten die de passeerbaarheid van een duiker kunnen vergroten zijn, de logische ligging met minimaal verval (voorkomen van hoge stroomsnelheden in de duiker), de ruwheid van het materiaal, de licht-donker verhouding en de aanwezigheid van zwakke stroming. Ook bij de uitstroomopening mag er geen hoogteverschil (stroomversnelling of waterval) optreden en moet in stromende wateren een luwtezone of poel na de uitstroom worden voorkomen.

\section{Stuwen en bodemdrempels}

Bodemdrempels zijn mindere barrières omdat ze zwemmend gepasseerd kunnen worden. Wel ontstaat er een slibophoping bovenstrooms en een stroomversnelling benedenstrooms van de drempel. Dit kan voor kruipende dieren een obstakel vormen.

Stuwen vormen echte barrières omdat ze tegen de waterbeweging in meestal niet passeerbaar zijn. Het verwijderen van stuwen heeft de voorkeur. In stromende wateren is dit geen probleem indien het watersysteem in z'n natuurlijke dal kan functioneren. In alle andere gevallen zijn oplossingen nodig om stuwen passeerbaar te maken. Een belangrijk effect van stuwen is de opstuwing bovenstrooms en de stroomversnelling benedenstrooms. Het slechts tijdelijk stuwen of minimaliseren van boven- en benedenstroomse effecten op de waterbeweging dragen sterk bij aan de passeerbaarheid. De aanleg van nevengeulen verbeteren de doorgang voor macroinvertebraten en vissen (Iversen et al. 1993, DVWK 2002). Voor een uitgebreid overzicht zie Roni et al. (2008).

Waterreservoirs, zandvangen e.d.

Stilstaande wateren in een stromend water, zoals reservoirs en zandvangen, functioneren als bezinkbassin voor slib, zand en voedingsstoffen met als gevolg een ophoping van organisch materiaal. Dit leidt tot verslechterde zuurstofomstandigheden in het aquatisch milieu (Klopatek 1978, Ebel 1985). Algengroei verhoogt de troebelheid van de waterkolom en tezamen met opwervelend fijne organische deeltjes zal de lichtpenetratie gering zijn. Dit beperkt de groei van wortelende vegetatie en epifytische algen en daarmee het voedselaanbod voor consumenten (Hart \& Fuller 1974, Alablaster \& Lloyd 1982). Troebelheid en zwevend stofgehalte beperken vismigratie, voeding, paaien, beweging en respiratie (McCarthy 1985). De afwezigheid van een stromingspatroon beperkt in sterke mate de stroomopwaartse migratie van vooral jonge vis, vooral in vermoeraste situaties zonder stroomgeul. Dergelijk stilstaande wateren worden als 'driftvallen' aangemerkt (Pechlaner 1986). De milieu-omstandigheden in stilstaande wateren zijn ongeschikt voor beekbewonende macro-evertebraten (Dendy 1944, Statzner 1979). Vissen zijn door hun afmetingen en zwemcapaciteit, in staat veel grotere afstanden af te leggen in vergelijking tot macroevertebraten. Maar ook voor vissen zijn bovengenoemde omstandigheden van belang, zij het op grotere schaal.

Maatregelen richten zich op het voorkomen van dergelijke stilstaande wateren die de stroomgeul onderbreken. Bij zandvangen moet het slib tijdig worden verwijderd en de afmetingen zo beperkt mogelijk worden gehouden. Volledige vermoerassing moet worden voorkomen. Grotere reservoirs kunnen als 'nevengeul' worden aangelegd, zoals molenvijvers, grachten of andere waterpartijen, zodat er een stroomgeul in de hoofdloop wordt behouden.

\subsection{Permanente connectiviteit}

Voor permanent watergebonden organismen zoals kreeftachtigen, tweekleppigen, slakken en platwormen is in stelsels van watergangen connectiviteit essentieel voor hun overleving tijdens extreme omstandigheden zoals perioden met droogval of ijsvorming maar ook bij incidentele calamiteiten. De dieren moeten zich dan ongehinderd kunnen verplaatsen om zo de meer geschikte plekken op te kunnen zoeken om de extremiteiten in milieu-omstandigheden te overleven en nadien de oorspronkelijk habitat opnieuw te kunnen bezetten. De snelheid van terugkeer hangt van de dispersiecapaciteit van de soort af. Het verwijderen van kunstwerken die werken als barrières is in wateren die gevoelig zijn voor extremen zijn daarom noodzakelijk om terugkeer te vergemakkelijken. 


\section{Conclusies}

Organismen verplaatsen zich in de ruimte binnen en tussen populaties, en naar nieuwe locaties. De verspreidingscapaciteit verschilt van soort tot soort. Dispersie is afhankelijk van de verspreidingscapaciteit van een soort, de wijze van verspreiding, de afstand en de omstandigheden in het te overbruggen aquatisch of terrestrisch landschap. Organismen kunnen zich actief of passief verspreiden. Planten verspreiden zich alleen passief. De meeste macroinvertebraten families verspreiden zich hoofdzakelijk passief en zowel het aantal families als de aantallen organismen die passief dispergeren zijn vele male groter dan de actieve verspreiders. Vissen verspreiden vooral actief.

Om verspreiding naar herstelde wateren te verbeteren is tijdens herstel aandacht nodig voor de doelsoorten, hun verspreidingscapaciteit, de plaatsen met bronpopulaties en de afstand en milieuomstandigheden tussen bronpopulaties en herstellocatie. Op basis van deze informatie kunnen extra maatregelen nodig zich om bronpopulaties te versterken en de verbinding met het herstelde water te verbeteren. 


\section{Literatuur}

Abellan, P., Millan, A. \& Ribera, I. (2009) Parallel habitat driven differences in the phylogeographical structure of two independent lineages of Mediterranean saline water beetles. Molecular Ecology, $18,3885-3902$.

Aho, J. (1966). Ecological basis of the distribution of the littoral freshwater molluscs in the vicinity of Tampere, South Finland. Ann. Zool. Fenn. 3: 287-322.

Alabaster, J.S. (1982). Habitat modification and freshwater fisheries. Proc. Symp. Europ. Inl. Fish.A.C. London. 278.

Avery, E.L. (1973). The influence of chemical reclamation on a small brown trout stream in southwestern Wisconsin. Tech. Bull. Dep. Nat. Resour. Madison. Wisconsin. No.110.

Bilton, D. T., R. Freeland, \& B. Okamura. 2001. Dispersal in freshwater invertebrates. Annu. Rev. Ecol. Syst. 32: 159-181. doi:10.1146/annurev.ecolsys.32.081501.114016

Bless, R. (1981). Untersuchungen zum Einfluss von gewässerbaulichen Massnahmen auf die Fischfauna in Mittelgebirgsbächen. Natur und Landschaft 56: 243-252.

Boedeltje, G., Bakker, J. P., Ten Brinke, A., Van Groenendael, J. M. \& Soesbergen, M. (2004) Dispersal phenology of hydrochorous plants in relation to discharge, seed release time and buoyancy of seeds: the flood pulse concept supported. Journal of Ecology, 92, 786-796.

Bohonak, A. J. \& Jenkins, D. G. (2003). Ecological and evolutionary significance of dispersal by freshwater invertebrates. Ecology Letters 6: 1-14.

Börger, L., Dalziel, B. D., \& Fryxell, J. M. (2008). Are there general mechanisms of animal home range behaviour? A review and prospects for future research. Ecology letters, 11(6), 637-650.

Brederveld, R. J., Jähnig, S. C., Lorenz, A. W., Brunzel, S., \& Soons, M. B. (2011). Dispersal as a limiting factor in the colonization of restored mountain streams by plants and macroinvertebrates. Journal of Applied Ecology, 48(5), 1241-1250.

Bulow, F.J., Webb M.A., Crumby W.D. \& Quisenberry S.S. (1988). Effectiveness of a Fish Barrier Dam in Limiting Movement of rough Fishes from a Reservoir into a Tributary Stream. N. Am. J. Fish. Mngmt. 8: 273-275.

Buijse, A. D., Verdonschot, R. C. M., van Puijenbroek, P., \& Verdonschot, P. F. M. (2019). De haarvaten van het ecologisch riviernetwerk: Consequenties van fragmentatie en het belang van landbruggen en oeverzones. Landschap: tijdschrift voor landschapsecologie en milieukunde, 36(2), 68-77.

Damm, S., Dijkstra, K.D.B. \& Hadrys, H. (2010) Red drifters and dark residents: the phylogeny and ecology of a PlioPleistocene dragonfly radiation reflects Africa's changing environment (Odonata, Libellulidae, Trithemis). Molecular Phylogenetics and Evolution, 54, 870-882.

Danthanarayana, W. (Ed.). (2012). Insect flight: dispersal and migration. Springer Science \& Business Media.

De Bie, T., De Meester, L., Brendonck, L., Martens, K., Goddeeris, B., Ercken, D., ... \& Declerck, S. A. J. (2012). Body size and dispersal mode as key traits determining metacommunity structure of aquatic organisms. Ecology letters, 15(7), 740-747.

Dendy, J.S. (1944). The fate of animals in stream drift when carried into lakes. Ecol. Monogr. 14: 333357.

Didderen, K. (2007). Dispersie: herstelde petgaten en de rol van dispersie (No. 1564). Alterra.

Didderen, K., Snoek, R. C., \& Verdonschot, P. F. M. (2008). Dispersie van macroinvertebraten door duikers: resultaten van een labexperiment (No. 1746). Alterra.

DVWK (Deutscher Verband fur Wasserwirtschaft und Kulturbau) (2002). Fish passes-design, dimensions and monitoring. Food and Agriculture Organization of the United Nations, Rome.

Ebel, W.J. (1985). Review of effects of environmental degradation on the freshwater stages of anadromous fish. In: Alabaster J.S. Habitat Modifications and Freshwater Fishes. Proc. Symp. Europ. Inland Fish. Butterworths, London. 62-82.

Elliott, J.M. (1971) Upstream movements of benthic invertebrates in a Lake District stream. Journal of Animal Ecology, 40, 235-252.

Figuerola, J. \& Green, A.J. (2002) Dispersal of aquatic organisms by water-birds: a review of past research and priorities for future studies. Freshwater Biology, 47, 483-494.

Finlay, B. J. \& T. Fenchel (2004). Cosmopolitan metapopulations of free-living microbial eukaryotes. Protist 155: 237- 244.

Gebhards S. \& Fisher J. (1972). Fish passage and culvert installations. Idaho Department of Fish and Game Boise, ID (Verenigde Staten): IFGD 12. 
Gurnell, A., Thompson, K., Goodson, J. \& Moggridge, H. (2008) Propagule deposition along river margins: linking hydrology and ecology. Journal of Ecology, 96, 553-565.

Hart, C.W. Jr. \& Fuller S.L.H. (1974). Pollution ecology of freshwater invertebrates. Academis Press, New York.

Heino, J. (2008). Patterns of functional biodiversity and function-environment relationships in lake littoral macroinvertebrates. Limnol. Oceanogr. 53: 1446-1455. doi:10.4319/lo.2008.53.4.1446.

Heino, J. (2013). Does dispersal ability affect the relative importance of environmental control and spatial structuring of littoral macroinvertebrate communities? Oecologia 171: 971-980. doi: $10.1007 / \mathrm{s} 00442-12-2451-4$

Heino, J., A. S. Melo, T. Siqueira, J. Soininen, S. Valanko, \& L. M. Bini (2015). Metacommunity organisation, spatial extent and dispersal in aquatic systems: Patterns, processes and prospects. Freshw. Biol. 60: 845-869. doi:10.1111/fwb.12533

Hof, C., Brandle, M. \& Brandl, R. (2006). Lentic odonates have larger and more northern ranges than lotic species. Journal of Biogeography, 33, 63-70.

Iversen, T. M., B. Kronvang, B. L. Madsen, P. Markmann, \& M. B. Nielsen (1993). Re-establishment of Danish streams: restoration and maintenance measures. Aquatic Conservation: Marine and Freshwater Ecosystems 3(2):73-92.

Johnson, R. K., \& W. Goedkoop (2002). Littoral macroinvertebrate communities: Spatial scale and ecological relationships. Freshw. Biol. 47: 1840-1854. doi:10.1046/j.1365-2427.2002.00932.x

Kay, A.R. \& Lewis, R.B. (1970). Passage of anadromous fish through highway drainage structures. In: Highway research report. State of California Sacramento, CA (Verenigde Staten): California Div. of Highways: 15.

Klopatek, J.M. (1978). Nutrient dynamics of freshwater riverine marshes and the role of emergent macrophytes. In R.E. Good, D.F. Whingham and R.L. Simpson (eds), Freshwater wetlands ecological processes and management potential. London: Academic Press.

Kratt, L.F. (1981). Evidence of Artic Grayling (Thymallus arcticus) Spawning in a Higway Culvert. Environ. Manage. Assoc. 1530-10 Ave. S.W. Calgary, Alta T3C OJ5, Canada.

Krieg, R., \& Zenker, A. (2020). A review of the use of physical barriers to stop the spread of non-indigenous crayfish species. Reviews in Fish Biology and Fisheries, 30, 423-435.

Lauman, J.E. (1976). Salmonis passage at stream-road crossings: A report with department standards for passage of salmonids. Oregon Department of Fish and Wildlife Portland, OR (Verenigde Staten): ODFW 78.

Leibold, M. A., \& Miller, T. E. (2004). From metapopulations to metacommunities. In Ecology, genetics and evolution of metapopulations (pp. 133-150). Academic Press.

Leibold, M. A., Holyoak, M., Mouquet, N., Amarasekare, P., Chase, J. M., Hoopes, M. F., ... \& Gonzalez, A. (2004). The metacommunity concept: a framework for multi-scale community ecology. Ecology letters, 7(7), 601-613.

Loreau, M., Mouquet, N., \& Holt, R. D. (2003). Meta-ecosystems: a theoretical framework for a spatial ecosystem ecology. Ecology Letters, 6(8), 673-679.

Malmqvist, B. (2002). Aquatic invertebrates in riverine landscapes. Freshwater Biology 47: 679-694.

McCarthy, D.T. (1985). The adverse effects of channalization and their amelioration. In: Alabaster J.S. Habitat Modifications and Freshwater Fishes. Proc. Symp. Europ. Inland Fish. Butterworths, London. 83-97.

Mouquet, N., \& M. Loreau (2003). Community patterns in source-sink metacommunities. Am. Nat. 162: 544-557. doi:10.1086/378857

Nijboer, R. C., \& Verdonschot, P. F. M. (2006). Dispersie van aquatische organismen; verspreidingsmogelijkheden en onderzoeksmethoden (No. 1365). Alterra.

Nilsson, C., Andersson, E., Merritt, D. M. \& Johansson, M. E. (2002). Differences in riparian flora between riverbanks and river lakeshores explained by dispersal traits. Ecology, 83, 2878-2887.

Ptatscheck, C. \& Traunspurger, W. (2020). The ability to get everywhere: dispersal modes of free-living, aquatic nematodes. Hydrobiologia 847, 3519-3547. https://doi.org/10.1007/s10750-020-04373$\underline{0}$

Pechlaner R. (1986). Traps for drift and barriers for the upward migration of invertebrates in the rhithral zone of running waters. (G.e.) Wass. Abwass. 30: 421-63.

Ribera, I. \& Vogler, A.P. (2000). Habitat type as a determinant of species range sizes: the example of lotic-lentic differences in aquatic Coleoptera. Biological Journal of the Linnean Society, 71, 33-52.

Riemersma, P. (1994). Biologische aspecten bij het ontwerp van vispassages. Vismigratie, visgeleiding en vispassages in Nederland. Organisatie ter Verbetering van de Binnenvisserij. Nieuwegein. 1-279. 
Roni, P., Hanson, K., \& Beechie, T. (2008). Global review of the physical and biological effectiveness of stream habitat rehabilitation techniques. North American Journal of Fisheries Management, 28(3), 856-890.

Saltzman W. \& Koski R.O. (1971). Fish passage through culverts. Oregon State Game Commission Portland, OR (Verenigde Staten): OSGC 3.

Sarremejane, R., Cid, N., Stubbington, R., Datry, T., Alp, M., Cañedo-Argüelles, M., ... \& Bonada, N. (2020). DISPERSE, a trait database to assess the dispersal potential of European aquatic macroinvertebrates. Scientific data, 7(1), 1-9.

Smit, H., Didderen, K., \& Wiggers, R. (2007). the first record of the watermite Arrenurus berolinensis from the netherlands, with the first description of the female (acari: hydrachnidia). Nederlandse Faunistische Mededelingen, 2007(26), 39-42.

Soons, M. B. (2006). Wind dispersal in freshwater wetlands: knowledge for conservation and restoration. Applied Vegetation Science, 9, 271-278.

Soons, M. B., Heil, G. W., Nathan, R. \& Katul, G. G. (2004). Determinants of long-distance seed dispersal by wind in grasslands. Ecology, 85, 3056-3068.

Soons, M.B., Van Der Vlugt, C., Van Lith, B., Heil, G.W. \& Klaassen, M. (2008) Small seed size increases the potential for dispersal of wetland plants by ducks. Journal of Ecology, 96, 619-627

Statzner, B. (1979). Der obere und Untere Schierenseebach (Schleswig-Holstein)., Strukturen und Funktionen in zwei norddeutschen See-Ausfluß-systemen, unter besonderer Berucksichtigung der Makroinvertebraten. Diss. Univ. Kiel.

Stubbington, R., England, J., Wood, P. J., \& Sefton, C. E. (2017). Temporary streams in temperate zones: recognizing, monitoring and restoring transitional aquatic-terrestrial ecosystems. Wiley Interdisciplinary Reviews: Water, 4(4), e1223.

Sundermann, A., Stoll, S., \& Haase, P. (2011). River restoration success depends on the species pool of the immediate surroundings. Ecological Applications, 21(6), 1962-1971.

Thompson, K., Bakker, J.P. \& Bekker, R.M. (1997). The Soil Seed Banks of North West Europe: Methodology, Density and Longevity. University Press, Cambridge.

Tolonen, K. T., H. Ham€ al $€$ ainen, I. J. Holopainen, and J. Karjalainen. 2001. Influences of habitat type and environmental variables on littoral macroinvertebrate communities in a large lake system. Arch. Hydrobiol. 152: 39-67.

Tonkin, J. D., Stoll, S., Sundermann, A., \& Haase, P. (2014). Dispersal distance and the pool of taxa, but not barriers, determine the colonisation of restored river reaches by benthic invertebrates. Freshwater Biology, 59(9), 1843-1855.

Turner, D. \& Williams, D.D. (2000). Invertebrate movements within a small stream: density dependence or compensating for drift? International Review of Hydrobiology, 85, 141-156.

Vanschoenwinkel, B., Gielen, S., Seaman, M. \& Brendonck, L. (2008). Any way the wind blows - frequent wind dispersal drives species sorting in ephemeral aquatic communities. Oikos, 117, 125-134.

Verdonschot, P.F.M. (1996). Migratie van beekmacrofauna en beekvissen; migreerbaarheid van een gesloten of open afleiding van de Schuitenbeek. IBN-rapport nr. 237:1-85.

Verdonschot, P.F.M. \& Verdonschot, R.C.M. (2020). Factsheet: Basisafvoer verhogen. Kennisimpuls Waterkwaliteit. Notitie Kennisimpuls waterkwaliteit (KIWK), Zoetwaterecosystemen, Wageningen Environmental Research, Wageningen UR, Wageningen. 15 pp.

Vilmi, A., S. M. Karjalainen, S. Hellsten, \& J. Heino. (2016). Bioassessment in a metacommunity context: Are diatom communities structured solely by species sorting? Ecol. Indic. 62: 86-94. doi: $10.1016 /$ j.ecolind.2015.11.043.

Wesselingh, F. P., Cadee, G. C. \& Renema, W. (1999). Flying high: On the airborne dispersal of aquatic organisms as illustrated by the distribution histories of the gastropod genera Tryonia and Planorbarius. Geologie en Mijnbouw 78 (2): 165-174.

Westveer, J. J., van der Geest, H. G., van Loon, E. E., \& Verdonschot, P. F. (2018). Connectivity and seasonality cause rapid taxonomic and functional trait succession within an invertebrate community after stream restoration. PloS one, 13(5), e0197182.

Wilke H. (1970). Absturzbauwerke und Fishaufstieg. Wasser und Boden 22: 352-354. 